\title{
Distribution, Blood Transport, and Degradation of Antidiuretic Hormone in Man
}

\author{
Gerhard Baumann and Joseph F. Dingman \\ From the Department of Medicine, Peter Bent Brigham Hospital, and \\ Harvard Medical School, Boston, Massachusetts 02115
}

\begin{abstract}
A в S T R A C T The distribution, blood transport, and metabolic clearance of physiological concentrations of antidiuretic hormone were studied in 10 hydrated normal subjects with radioiodinated arginine vasopressin ( $\left.{ }^{125} \mathrm{I}-\mathrm{AVP}\right)$. At $37^{\circ} \mathrm{C}$ no binding of ${ }^{125} \mathrm{I}-\mathrm{AVP}$ to plasma proteins could be demonstrated, but some metabolites were associated with plasma proteins. ${ }^{125} \mathrm{I}-\mathrm{AVP}$ was rapidly distributed into a space approximating the extracellular fluid volume. Metabolic breakdown products became demonstrable within minutes after injection. The mean metabolic clearance rate of ${ }^{125} \mathrm{I}-\mathrm{AVP}$ was 4.1 $\mathrm{ml} / \mathrm{min} / \mathrm{kg}$ and the mean plasma half-life $24.1 \mathrm{~min}$. Renal clearance had a mean value of $80 \mathrm{ml} / \mathrm{min}$ and accounted for $27 \%$ of the total metabolic clearance. It is concluded that in man antidiuretic hormone circulates as a free (non-protein bound) peptide, diffuses readily into the extracellular fluid space, and is metabolized within minutes. A plasma half-life of $24 \mathrm{~min}$ is consistent with the duration of antidiuresis after hormone administration or release.
\end{abstract}

\section{INTRODUCTION}

Studies of the metabolic fate of circulating vasopressin (antidiuretic hormone, ADH) ${ }^{1}$ have been hindered by the lack of reliable methods for hormone measurement,

A preliminary report of this work has appeared in Program of the 53rd Meeting of the Endocrine Society, No. 250, 1971.

Dr. Baumann was a Visiting Investigator of the Howard Hughes Medical Institute. His present address is Reproduction Research Branch, National Institute of Child Health and Human Development, National Institutes of Health, Bethesda, Md. 20014.

Received for publication 9 January 1973 and in revised form 17 December 1975.

${ }^{1}$ Abbreviations used in this paper: ADH, antidiuretic hormone; AVP, arginine vasopressin; LVP, lysine vasopressin; MCR, metabolic clearance rate; Uosm, urinary osmolality. and very rapid metabolism resulting in unsteady test conditions. Many experiments using bioassay have been performed in laboratory animals. Some human studies have been reported, but much of the data remain controversial, mainly due to the low specificity of bioassays and to species differences (see ref. 1 for review). Radioisotopically labeled $\mathrm{ADH}$ could overcome some of these difficulties but only few studies have been reported heretofore (2-4). The labeled $\mathrm{ADH}$ used in these reports was of low specific activity, which required administration of supraphysiological quantities of hormone. Only limited data on $\mathrm{ADH}$ metabolism from radioimmunoassays have been reported to date (5-8). In the present report we have used radioiodinated arginine vasopressin (AVP) to study the metabolism of $A D H$ in man at physiological plasma concentrations.

\section{METHODS}

AVP peptides. The synthetic AVP used in these studies was a gift from Sandoz Ltd., Basel, Switzerland. It had a specific bioactivity of $470 \mathrm{U} / \mathrm{mg}$ when assayed against USP bovine posterior pituitary standard in the ethanol-anesthetized diuretic rat and in the rat pressor assay. On glass paper chromatography it showed a single component that co-chromatographed with natural AVP. Natural AVP was prepared from bovine posterior pituitary powder by the method of Schally et al. (9) and used as a standard in paper chromatography and electrophoresis. This material exhibited a bioactivity of $435 \mathrm{U} / \mathrm{mg}$ and was chromatographically homogeneous. The synthetic AVP used as a fluorimetric standard was obtained from Schwarz/Mann Div., Becton, Dickinson \& Co., Orangeburg, N. Y., and had a stated potency of over $270 \mathrm{U} / \mathrm{mg}$. It showed two components on paper chromatography.

Radioiodination and purification. A modification of the chloramine $\mathrm{T}$ method (10) for iodination was used. $2 \mathrm{mCi}$ of carrier-free ${ }^{125} \mathrm{I}$ as $\mathrm{NaI}$ (Cambridge Nuclear Corp., Cambridge, Mass.), $0.1 \mathrm{ml}$ of $0.5 \mathrm{M}$ sodium phosphate buffer, $\mathrm{pH} 7.4,1 \mu \mathrm{g}$ of synthetic AVP (Sandoz) and $50 \mu \mathrm{l}$ of freshly prepared chloramine $\mathrm{T}(0.35 \%)$ were added to the reaction vessel. No reducing agent was used. The mixture was transferred to a column of $1.0 \mathrm{~cm}$ diameter containing $2 \mathrm{~cm}$ of Dowex 2X8 (Dow Chemical USA, Midland, Mich.) 
at the bottom and $23 \mathrm{~cm}$ Sephadex G-25 (fine) (Pharmacia Fine Chemicals, Inc., Piscataway, N. J.) at the top. The column had been equilibrated with $0.25 \%$ acetic acid and standardized with blue dextran and $\mathrm{Na}^{125}$ I. The same solvent was used for elution.

In parallel experiments, recovery from a similar column was estimated as follows: 5 ug of AVP (Sandoz) was iodinated and purified by the identical procedure. The peptide concentration in this preparation was estimated by the fluorescamine reaction (11), with synthetic AVP (Schwarz/ Mann) and bacitracin (Sigma Chemical Co., Inc., St. Louis, Mo.) as standards. An aliquot containing $1 \mu \mathrm{g}{ }^{225} \mathrm{I}$ AVP was then passed through the column and recovery was determined on the basis of radioactivity. Recovery was $10.2 \%$.

Purity of the labeled material was established by ascending chromatography on silicic acid-impregnated glass paper (ChromAR 500, Mallinckrodt Inc., St. Louis, Mo.) in a slow and a fast solvent system ( $n$-butanol: acetic acid: water $=8: 2: 3$ and $8: 3: 4.5$ ). Unlabeled natural AVP was used as a standard in all experiments and stained with the Folin-Ciocalteu reagent. A single radioactive peak was observed with the $R_{f}$ of unlabeled AVP in both systems (Fig. 1). The material was also subjected to electrophoresis on Whatman No. 3 paper in acetate buffer, $0.03 \mathrm{M}$. pH 3.8. and in phosphate buffer, $0.03 \mathrm{M}, \mathrm{pH} 6.4$. At $\mathrm{pH} 3.8$, the radioactive peak showed the mobility of AVP. At $\mathrm{pH} 6.4$, a single radioactive peak was again observed, but it had a slightly slower mobility than AVP (Fig. 2). This finding is compatible with the shift of the $\mathrm{pK}$ of the phenolic hydroxyl group from 10.1 to 8.2 with mono-iodination (12). The material was also compared to the original AVP by discontinuous polyacrylamide gel electrophoresis in a cationic $\beta$-alanine/acetic acid/KOH buffer system, ionic strength 0.015 , operative $\mathrm{pH} 3.5,0^{\circ} \mathrm{C}$ (System $29,[13]$ ), at four different gel concentrations $(10,15,20$, and $30 \%)$. Coomassie brilliant blue G-250 was used for staining. A single band with a mobility indistinguishable from that of AVP was found. The retardation coefficient was 0.023 , and the relative free mobility was 0.820 for both peptides (14).

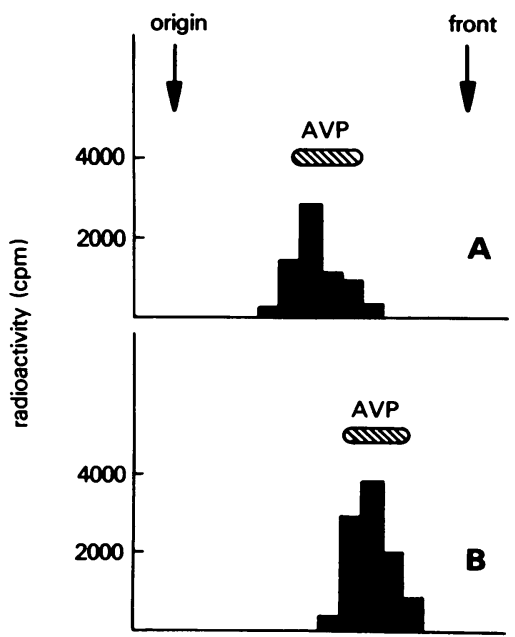

FIgURE 1 Glass fiber paper chromatography of ${ }^{125}$ I-AVP in A. $n$-butanol: acetic acid: water $=8: 2: 3$; B. n-butanol : acetic acid: water $=8: 4: 4.5$. The position of unlabeled AVP is indicated.

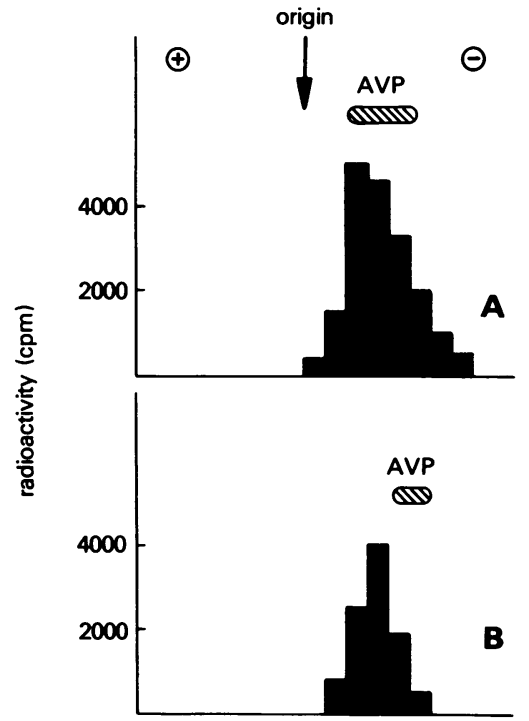

FiguRE 2 Chromatoelectrophoresis of ${ }^{125}$ I-AVP on Whatman No. 3 paper. A. $0.03 \mathrm{M}$ acetate buffer, pH 3.8. B. 0.03 $\mathrm{M}$ phosphate buffer, $\mathrm{pH}$ 6.4. The position of unlabeled AVP is indicated.

This material was considered to show the properties of monoiodo-AVP and was stored at $4^{\circ} \mathrm{C}$ in $0.25 \%$ acetic acid. It proved to be stable under these conditions for several weeks. Initial specific activities, as estimated from the radioactivity under the AVP peak and the peptide recovery, were 334,364 , and $492 \mathrm{mCi} / \mathrm{mg}$ in three batches used. Before each use, the peptide was repurified by passing it over a Dowex $2 \times 8$ column and purity was verified by paper chromatography. The solution was then adjusted to $\mathrm{pH} 5.0$ with $\mathrm{NaOH}$ and filtered into a vial containing sterile saline through a Millipore filter (pore diameter $0.22 \mu \mathrm{m}$ ) (Millipore Corp., Bedford, Mass.). The resulting solution was shown to be sterile and pyrogen-free.

Subjects and study protocol. 10 normal volunteers who gave their informed consent ( 5 men, 5 women, ages 20-29 yr) were studied. The subjects were allowed an ad libitum breakfast and reclined in a supine position for $1 \mathrm{~h}$ before study. They received 10 drops of saturated potassium iodide solution to block thyroidal iodine uptake. A $20 \mathrm{ml} / \mathrm{kg}$ water load was given to induce a high urine flow and to suppress endogenous $\mathrm{ADH}$. $90 \mathrm{~min}$ after hydration, $2-7 \mu \mathrm{Ci}(9.5-95$ ng) ${ }^{125}$ I-AVP were injected intravenously simultaneously with or preceded by $5 \mu \mathrm{Ci}$ of ${ }^{181} \mathrm{I}$-labeled human serum albumin (E. R. Squibb \& Sons, Princeton, N. J.), the latter to measure plasma volume and "mixing time". Blood was drawn from the opposite antecubital vein through an indwelling catheter into heparinized plastic syringes at frequent intervals for $60 \mathrm{~min}$ after the injection. Total blood loss was $90 \mathrm{ml}$. Blood samples for AVP isolation were chilled immediately to $0^{\circ} \mathrm{C}$ and processed as described below. Voided urine samples were collected at $10,20,30,45$, and 60 $\min$.

Assays. A dual-channel gamma spectrometer was used for radioactive counting. All samples were counted to an error of less than $2 \%$. 2-ml aliquots of plasma and urine were counted; blood cells were counted after washing with normal saline. Urinary osmolality ( $U_{o s m}$ ) was determined by freezing point depression. 
Binding of ${ }^{125} \mathrm{I}-\mathrm{AVP}$ to plasma proteins in vitro was studied by gel chromatography. To $1-\mathrm{ml}$ aliquots of plasma from a hydrated subject $5 \mathrm{pg}$ of ${ }^{125} \mathrm{I}$-AVP was added with or without the addition of $500 \mathrm{KIU}$ of bovine kallikreintrypsin inhibitor (Trasylol, Bayer, Leverkusen, W. Germany). Unlabeled AVP was added to parallel samples in amounts of $0,20,200$, and 2,000 pg. Gel chromatography was then immediately carried out on a $13 \times 0.9-\mathrm{cm}$ Sephadex G-15 column at $37^{\circ} \mathrm{C}$. The column had been equilibrated

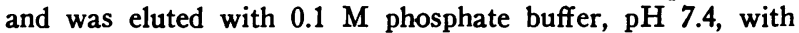
or without addition of Trasylol $(500 \mathrm{KIU} / \mathrm{ml})$. Flow rate was $1 \mathrm{ml} / \mathrm{min}$. In vivo binding of isotope to plasma proteins was measured in the blood samples obtained after injection by the dextran-coated charcoal method (15). A suspension of $100 \mathrm{mg} / \mathrm{ml}$ charcoal (Norit A, Fisher Scientific Co., Pittsburgh, Pa.) and $10 \mathrm{mg} / \mathrm{ml}$ dextran (Schwarz/ Mann clinical grade) was prepared in $0.05 \mathrm{M}$ phosphate buffer, $\mathrm{pH} 7.4$. $1 \mathrm{ml}$ of this suspension was mixed with $1 \mathrm{ml}$ of plasma at $4^{\circ} \mathrm{C}$, incubated at $4^{\circ} \mathrm{C}$ for $10 \mathrm{~min}$, and centrifuged. Radioactivity in the pellet and supernate was determined.

In search of AVP breakdown products, radiochromatography was performed on unextracted urine and on plasma extracts. Urine samples collected from 0 to 10,10 to 20,20 to 30,30 to 45 , and 45 to $60 \mathrm{~min}$ after injection were chromatographed in one of the systems described above (nbutanol: acetic acid: water $=8: 2: 3)$. The radiochromatograms were cut into $10-\mathrm{mm}$-wide strips and counted. For the characterization of radioactive material in blood, samples obtained at $6,12,16$, and $20 \mathrm{~min}$ after injection were extracted as follows: Blood was chilled to $0^{\circ} \mathrm{C}$ immediately after withdrawal and centrifuged at $4^{\circ} \mathrm{C}$ within $10 \mathrm{~min}$. The plasma proteins were precipitated with 2 vol of $10 \%$ trichloroacetic acid. The supernate containing ${ }^{105} \mathrm{I}$-AVP was extracted twice with diethyl ether to remove trichloroacetic acid, evaporated to a small volume, and chromatographed as described.

Calculations. Plasma radioactivity disappearance curves based on the chromatographically intact fraction of ${ }^{205} \mathrm{I}-\mathrm{AVP}$ were fitted over the range from 6 to $20 \mathrm{~min}$ in each study by least squares after logarithmic transformation of the ordinate. From these a mean disappearance curve was calculated. The chromatographically intact ${ }^{100}$ I-AVP was directly measured in sample withdrawn at $6,12,16$, and 20 min and estimated by interpolation at the other time points. Apparent volume of distribution $\left(V_{d}\right)$ of ${ }^{105}$ I-AVP was determined by extrapolation of the slope $(k)$ to zero time. Plasma volume was calculated from isotope dilution of the ${ }^{191}$ I-labeled albumin. Maximal initial plasma concentration of ${ }^{205}$ I-AVP was calculated as the dose administered divided by the plasma volume. Approximate renal clearance was calculated as total radioactivity excreted divided by the mean plasma radioactivity concentration during the collection period. Metabolic clearance rates (MCR) were calculated as the apparent volume of distribution times the slope of plasma disappearance.

\section{RESULTS}

Effect of ${ }^{125} I-A V P$ on urinary flow and osmolality. The ${ }^{12} \mathrm{I}$-AVP in doses from 9.5 to $25 \mathrm{ng}$ had no detectable antidiuretic action in six subjects, with urine flow ranging from 7 to $15 \mathrm{ml} / \mathrm{min}$ and $U_{o s m}$ remaining below $100 \mathrm{mosmol} / \mathrm{kg}$. One woman given $19 \mathrm{ng}$ had an initial urine flow of $1.0 \mathrm{ml} / \mathrm{min}$ and a Uosm above 600 mosmol/ $\mathrm{kg}$ that persisted for the $1-\mathrm{h}$ period of observa- tion. Because of technical problems, blood was obtained from this subject only with great difficulty, which resulted in considerable pain and stress. One male subject who showed marked apprehension was unable to void until $25 \mathrm{~min}$ after the injection; the urine passed at that time had a $U_{\text {osm }}$ of $82 \mathrm{mosmol} / \mathrm{kg}$. The female subject who received $95 \mathrm{ng}$ showed a fall in urine flow from 16 to $3.5 \mathrm{ml} / \mathrm{min}$ with a concomitant increase in Uosm from 87 to $270 \mathrm{mosmol} / \mathrm{kg}$ over a 10 -min period after the injection. In this subject urine osmolality reached a peak value at $30 \mathrm{~min}$ after injection (336 mosmol $/ \mathrm{kg}$ ) and fell thereafter to $260 \mathrm{mosmol} / \mathrm{kg}$ at 60 $\min$.

Distribution of ${ }^{125} I-A V P$. The individual data are summarized in Table $I$. The plasma radioactive disappearance curve of chromatographically intact ${ }^{125} \mathrm{I}$ AVP followed an at least double exponential function, with a single exponential component from 10 to $20 \mathrm{~min}$ (Fig. 3). Mixing time after injection, as indicated by stabilization of plasma ${ }^{131} \mathrm{I}$ concentration, ranged from 4 to $6 \mathrm{~min}$.

The apparent distribution volume of ${ }^{125} \mathrm{I}-\mathrm{AVP}$ had a mean value of $9,940 \mathrm{ml}$, or $140.8 \mathrm{ml} / \mathrm{kg}$ body wt. Plasma volume averaged $3,511 \mathrm{ml}$ or $48.9 \mathrm{ml} / \mathrm{kg}$.

Blood cells did not bind either isotope during the first $20 \mathrm{~min}$ after injection. No measurements were made thereafter.

Initial plasma concentrations of ${ }^{125} \mathrm{I}-\mathrm{AVP}$ were within those seen under physiological conditions $(5-7,16-18)$ (Table I).

Binding of ${ }^{12} I-A V P$ by plasma proteins. Gel chromatography patterns of ${ }^{150} \mathrm{I}-\mathrm{AVP}$ added to plasma in

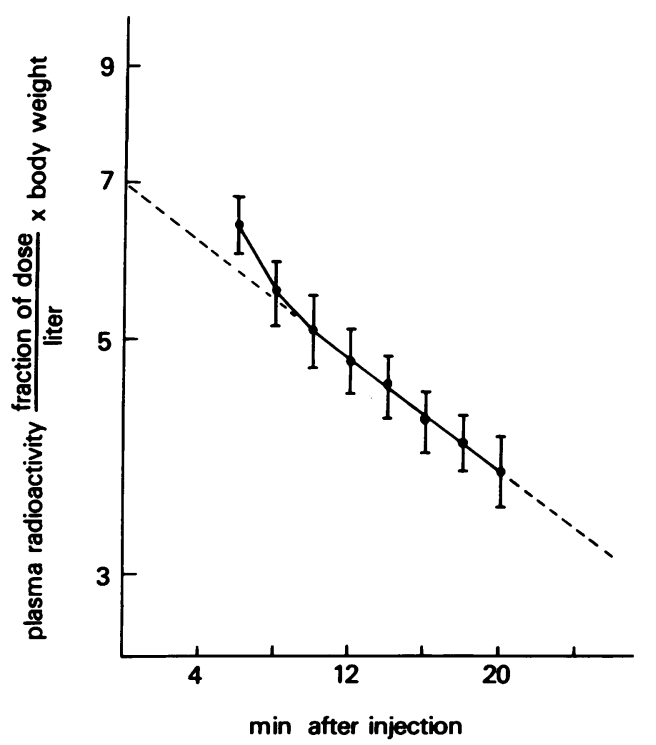

FIgURE 3 Plasma disappearance curve of chromatographically intact ${ }^{105}$ I-AVP (mean \pm SEM). 
TABLE I

A VP Distribution Data in 10 Normal Young Volunteers

\begin{tabular}{|c|c|c|c|c|c|c|c|c|c|c|c|}
\hline & Sex & Weight & $\begin{array}{c}\text { AVP } \\
\text { injected }\end{array}$ & $\begin{array}{l}\text { Calculated } \\
\text { initial } \\
\text { AVP } \\
\text { plasma } \\
\text { concn. }\end{array}$ & $\begin{array}{c}\text { Plasma } \\
\text { vol }\end{array}$ & $V_{d}$ & $\mathbf{k}$ & $t_{1}$ & MCR & $\begin{array}{c}\text { Renal } \\
\text { clearance } \\
(0-10 \mathrm{~min})\end{array}$ & $\begin{array}{l}\text { Isotope } \\
\text { excreted }\end{array}$ \\
\hline & & $k g$ & $n g$ & $p g / m l$ & $m l / k g$ & $\mathrm{ml} / \mathrm{kg}$ & $\min ^{-1}$ & $\min$ & $\mathrm{ml} / \mathrm{min} / \mathrm{kg}$ & $\mathrm{ml} / \mathrm{min} / \mathrm{kg}$ & $\% / 24 h$ \\
\hline F. W. & $\mathbf{F}$ & 60 & 95 & 28 & 55.8 & 175 & 0.0288 & 24.1 & 5.0 & 1.88 & 100 \\
\hline D. W. & $\mathbf{M}$ & 92 & 25.5 & 6.3 & 44.0 & 118 & 0.0293 & 23.7 & 3.5 & 1.27 & 96 \\
\hline T.C. & $\mathbf{M}$ & 82 & 19 & 4.5 & 51.5 & 110 & 0.0223 & 31.1 & 2.5 & 1.36 & 100 \\
\hline D. H. & $\mathbf{F}$ & 61 & 19 & 7.7 & 40.3 & 147 & 0.0312 & 22.2 & 4.6 & 0.78 & 80 \\
\hline R. K. & $\mathbf{M}$ & 79 & 19 & 4.6 & 52.2 & 149 & 0.0236 & 29.4 & 3.5 & 0.61 & - \\
\hline M.S. & $\mathbf{F}$ & 58 & 19 & 6.1 & 53.4 & 140 & 0.0318 & 21.8 & 4.5 & $(0.12)^{*}$ & 84 \\
\hline F. M. & M & 71 & 9.5 & 2.2 & 60.0 & 133 & 0.0369 & 18.8 & 4.9 & - & - \\
\hline D. M. & $\mathbf{M}$ & 83 & 9.5 & 2.3 & 49.0 & 112 & 0.0325 & 21.3 & 3.6 & $0.64 \ddagger$ & 78 \\
\hline L. .K. & $\mathbf{F}$ & 55 & 9.5 & 3.7 & 47.1 & 185 & 0.0280 & 24.8 & 5.2 & 0.67 & 100 \\
\hline P.O. & $\mathbf{F}$ & 65 & 9.5 & 4.1 & 35.6 & 139 & 0.0293 & 23.7 & 4.1 & 1.82 & 93 \\
\hline Mean & & 70.6 & & & 48.9 & 140.8 & 0.0288 & 24.1 & 4.14 & 1.13 & \\
\hline SEM & & 4.0 & & & 2.33 & 7.88 & 0.0013 & 1.17 & 0.27 & 0.26 & \\
\hline
\end{tabular}

$V_{d}$, apparent volume of distribution; $\mathbf{k}$, fractional disappearance rate from plasma.

* Subject with unexplained low urinary excretion, not included in mean.

¥ Subject unable to void for the first $25 \mathrm{~min}$ : value calculated over a 25 -min period.

vitro are shown in Fig. 4. No evidence for specific binding of intact ${ }^{125} \mathrm{I}$-AVP to plasma proteins was found. The radioactivity present in the macromolecular fractions was not displaceable by addition of up to 400 -fold excess of unlabeled AVP. Trasylol appeared to inhibit enzymatic breakdown of AVP in plasma substantially during the $15 \mathrm{~min}$ required for gel filtration, although some residual enzymatic activity remained. AVP metabolites appeared to be at least partially bound to plasma proteins, as demonstrated by the greater amount of radioactivity present in the macromolecular fractions in the absence of the protease inhibitor (Fig. 4, Table II). Protein binding of isotope in vivo, as determined by charcoal, gradually increased from $23 \%$ at $4 \mathrm{~min}$ to $40 \%$ at $60 \mathrm{~min}$. Over $90 \%$ of the ${ }^{131} \mathrm{I}$ injected remained protein-bound throughout the study period.

Metabolic breakdown. ${ }^{125} \mathrm{I}-\mathrm{AVP}$ appeared in the urine within the first $10 \mathrm{~min}$, whereas ${ }^{131} \mathrm{I}$-albumin was not excreted in the urine during the period of study. Chromatography of the urinary material showed only intact ${ }^{125} \mathrm{I}-\mathrm{AVP}$ in four of eight subjects during the first $10 \mathrm{~min}$ after injection. In the remainder, less than $15 \%$ of the radioactive compounds found were break-

TABLE II

Distribution of Radioactivity on Gel Chromatography of ${ }^{125} I-A V P$ Added to Plasma

\begin{tabular}{lcc}
\hline & $\begin{array}{c}\text { Macromolecular } \\
\text { fraction }\end{array}$ & $\begin{array}{c}\text { AVP } \\
\text { peak }\end{array}$ \\
\hline & $\%$ & $\%$ \\
With Trasylol & 6 & 82 \\
Without Trasylol & 20 & 78 \\
\hline
\end{tabular}

down products. Between 10 and 20 min radioactive compounds other than AVP became detectable in all subjects (Fig. 5).

Chromatography of plasma extracts showed an average of $6 \%$ breakdown products at $6 \mathrm{~min}$ and $10 \%$ at 12 min after injection. At 16 and 20 min detectable radioactive compounds other than ${ }^{125} \mathrm{I}-\mathrm{AVP}$ had risen to 13 and $16 \%$, respectively (Fig. 6 ). No radioactivity was found in the ether extract of the plasma in any instance. The 24-h urinary excretion of ${ }^{125} \mathrm{I}$ ranged from 78 to $100 \%$.

Clearance. MCR of intact ${ }^{125} \mathrm{I}-\mathrm{AVP}$, based on the slope of the plasma disappearance curve between 10 and $20 \mathrm{~min}$, had a mean value of $4.14 \mathrm{ml} / \mathrm{min} / \mathrm{kg}$. The mean half-life of ${ }^{125} \mathrm{I}-\mathrm{AVP}$, derived from the same section of the disappearance curve, was $24.1 \mathrm{~min}$, and the fractional disappearance rate was $0.0288 \mathrm{~min}^{-1}$ (Table I).

Renal clearance of ${ }^{125} \mathrm{I}$ within the first $10 \mathrm{~min}$ after injection ranged from 36.6 to $118 \mathrm{ml} / \mathrm{min}$ (mean 80 $\mathrm{ml} / \mathrm{min}$ ). One subject showed a very low initial isotope excretion with a urinary clearance of only $6 \mathrm{ml} / \mathrm{min}$. These values can only be rough estimates since they are based on voided urine samples and on crude approximation of a "mean" plasma concentration during the distribution phase.

\section{DISCUSSION}

The use of ${ }^{125} \mathrm{I}-\mathrm{AVP}$ has enabled us to make multiple measurements with relative ease and with far greater accuracy than can be obtained with bioassays. Bioassays and specific immunoassays, however, measure only the intact hormone, while the present method includes any 


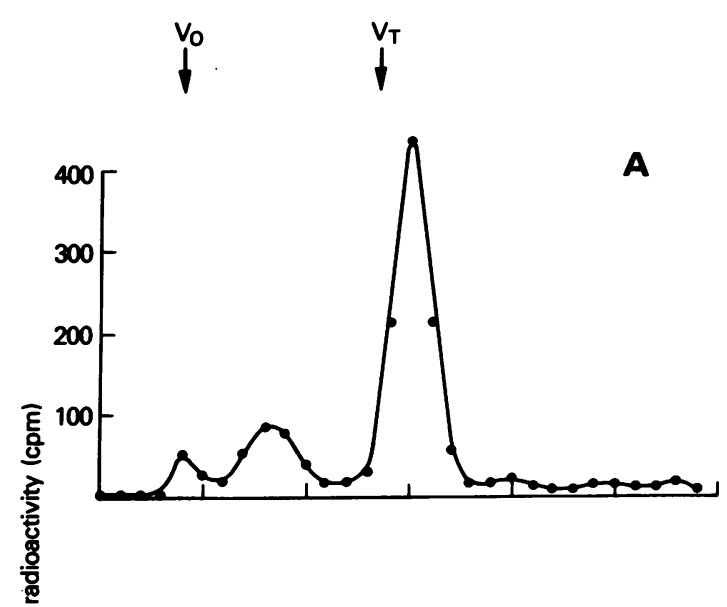

B

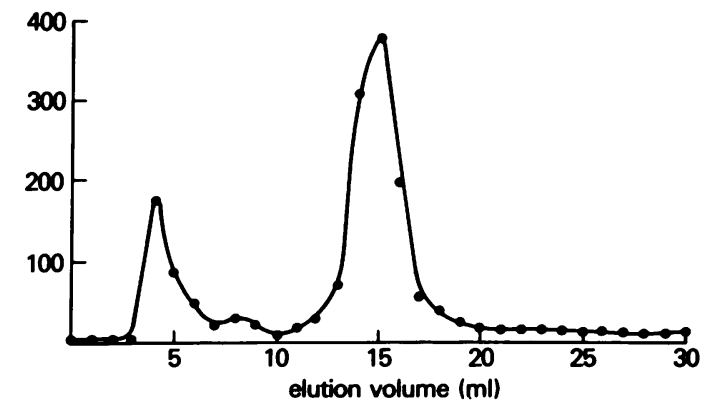

FIGURE 4 Gel chromatography of plasma containing ${ }^{185}$ I-AVP on Sephadex G-15 at $37^{\circ} \mathrm{C}$. A. Elution profile in the presence of Trasylol $(500 \mathrm{KIU} / \mathrm{ml})$. B. Elution profile without Trasylol. $V_{0}$ denotes the void volume, $V_{T}$ the total bed volume of the column.

possible radioactive metabolites. .Examination of metabolic breakdown is therefore important before any conclusions can be drawn. Our data show that radioactive breakdown products appear within minutes after injection.

The purity of the ${ }^{120} \mathrm{I}-\mathrm{AVP}$ used was established by showing homogeneity and chemical behavior similar to AVP in six different systems. The preparation appeared to be biologically active, as judged by the antidiuretic response of the subject who received a sufficient dose of peptide (F. W.). Whether this antidiuretic activity was due to the iodinated hormone or to the presence of unlabeled hormone in the preparation cannot be determined from the present data.

In contrast to numerous distribution studies with unlabeled vasopressin with bioassay, only few with radioactive hormone have been reported. Silver et al. (2) and Sjöholm and Rydén (3) used tritiated and iodinated vasopressin in distribution studies in dogs, rats, and man. Their preparations had low specific activities ranging from 0.4 to $2.4 \mathrm{mCi} / \mathrm{mg}$, with the result that unphysiologically high peptide doses were administered

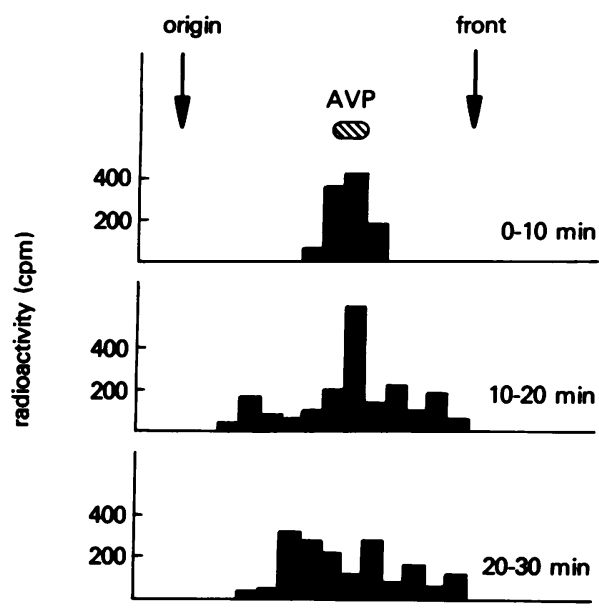

FIGURE 5 Glass paper chromatography of urinary ${ }^{120} \mathrm{I}$ at different times after injection in n-butanol: acetic acid: water $=8: 2: 3$. A representative pattern is shown. The position of unlabeled AVP is indicated.

(1-12.5 U i.v.). Klein and Roth (4) used ${ }^{131} \mathrm{I}-\mathrm{AVP}$ in man, but the amount of peptide given is not stated. In the present study the use of a peptide with sufficiently high specific activity resulted in physiological plasma concentrations.

A constant infusion technique to achieve steady-state conditions would have been preferable to the transientstate conditions used here. However, because of the rapid clearance of $\mathrm{ADH}$ from blood a steady-state could only be achieved by a high infusion rate. Since our studies were done in humans, the large amounts of

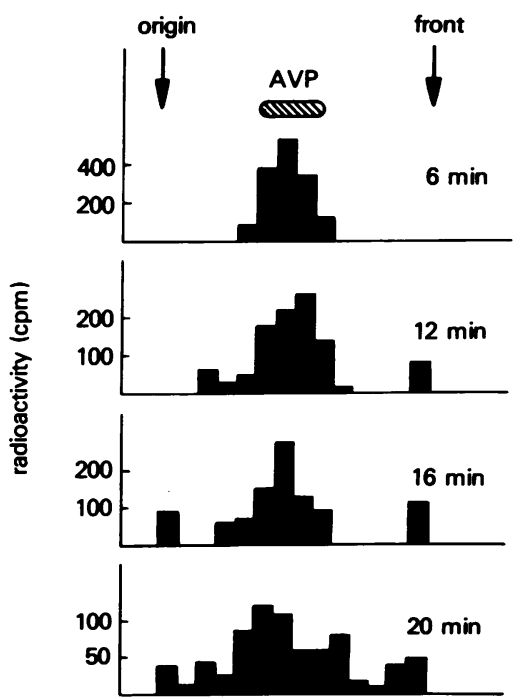

FIGURE 6 Glass paper chromatography of plasma extracts at different times after injection in the solvent system used in Fig. 5. A representative example is shown. The position of unlabeled AVP is indicated. 
radioactive iodine required to attain a steady-state precluded this approach.

Objections against the use of iodinated hormones as representatives for native hormones can be raised on the basis of their chemical difference. Identical metabolism of iodo-derivatives and original hormones have been shown for larger protein hormones, such as human growth hormone (19). Little information on the effect of iodination on the metabolism of small peptide hormones is available. Klein and Roth (4) reported differences between the metabolism of iodo-AVP and AVP, but subsequently their anti-AVP antibody was shown to lack specificity (20). More studies are needed to clarify the effect of iodination on action and metabolism of small peptide hormones. The preservation of molecular integrity, as judged by retention of biological activity, appears to be more related to the conditions of iodination than to the incorporation of an iodine atom. Thus, Fong et al. (21) reported that iodo-AVP was only $1 / 100$ as active as AVP, while Thompson et al. (22), using milder iodination conditions, found $80 \%$ of the bioactivity retained in iodo-oxytocin. The fact that our preparation was biologically active-although not proving activity of the iodinated species-and the agreement of our metabolic data with those obtained by other methods suggest that the peptide was not profoundly altered during iodination.

The radioactivity disappearance curve from plasma followed a double exponential function, with a rapid distribution component and a slower clearance component. Further components appeared beyond $10 \mathrm{~min}$, presumably reflecting radioactive breakdown products with different distribution and clearance characteristics. Elimination of these compounds by chromatography resulted in a nearly ideal fit to a single exponential function beyond $10 \mathrm{~min}$ (Fig. 3). The first 4-6 min after injection were'needed for uniform mixing in the blood, as judged by the stabilization of the ${ }^{131} \mathrm{I}$-albumin concentration. The measurements of ${ }^{125} \mathrm{I}-\mathrm{AVP}$ at 2 and $4 \mathrm{~min}$ after injection were therefore disregarded. The mean half-life of $24.1 \mathrm{~min}$ agrees closely with that reported for the disappearance of exogenous Pitressin by Robertson and co-workers (6), using a highly specific radioimmunoassay for AVP. Beardwell (5) and Skowsky et al. (7) reported somewhat shorter halflives for Pitressin, but their assays did not distinguish between lysine vasopressin (LVP) and AVP, both of which are present in Pitressin. The faster disappearance rates in their studies may well reflect more rapid metabolism of LVP, a "foreign" peptide to man. A more rapid turnover of LVP than AVP in man has been demonstrated by indirect methods by Miller et al. (23).

Earlier half-life estimations, using bioassay, have mostly been performed in the rat and dog (see ref. 1 for review). They cannot be taken as directly repre- sentative for man. Most experiments in man were done at supraphysiological plasma concentrations. Schröder and Rott (24) showed a half-life of $8 \mathrm{~min}$ at a plasma level of $420 \mu \mathrm{U} / \mathrm{ml}$ in man. Czaczkes et al. reported half-lives from 10 to $44 \mathrm{~min}$ in normal subjects, depending on hydration (25). Plasma concentrations of exogenous and endogenous $\mathrm{ADH}$ were in the physiological range in their experiments, but bioassays of unextracted plasma lack sufficient specificity. More recently Miller et al. published a half-life of 23-25 min, based on the biological response of the kidney (23). Using radioactive AVP, Silver et al. (2) reported halflives of 3.2 to $6.5 \mathrm{~min}$ in two subjects. From the analysis of their disappearance curves it appears that they chose a very early phase with a rapidly changing slope for their calculations in addition to administration of amounts far exceeding physiological doses.

Species differences, inaccuracy of bioassays, insufficient specificity of immunoassays, turnover differences between LVP and AVP, different states of hydration, and varying plasma AVP concentrations could explain the apparent discrepancies of earlier studies.

The question of binding of $\mathrm{ADH}$ to plasma proteins has been particularly controversial. Data ranging from complete to no binding have been published (see ref. 1 for review). Ultrafiltration, equilibrium dialysis, gel chromatography, electrophoresis, and peritoneal dialysis have been employed to separate bound from free hormone. Since bioassay was used in all these studies, the question of specificity clouds the interpretation of results. Our data suggest that intact ${ }^{125} \mathrm{I}-\mathrm{AVP}$ is not bound appreciably to plasma proteins at physiological concentrations at $37^{\circ} \mathrm{C}$. The significantly greater amount of radioactivity associated with the protein peak in the absence of Trasylol suggests that at least some enzymatic breakdown products of $\mathrm{ADH}$ are bound to plasma proteins. Likewise, protein-bound radioactivity in vivo increased gradually with time, an observation consistent with binding of metabolites to plasma proteins. ${ }^{125} \mathrm{I}$-AVP was rapidly distributed into a space equaling the extracellular fluid volume. The molecular size and lack of protein binding of $\mathrm{ADH}$ appear consistent with its rapid equilibration within the extracellular fluid space.

The MCR of ${ }^{125} \mathrm{I}-\mathrm{AVP}$ from blood, ranging from 2.5 to $5.2 \mathrm{ml} / \mathrm{min} / \mathrm{kg}$, falls within the range calculated from other reported data in humans $(24,25)$.

In eight subjects in whom renal clearance could be measured, ${ }^{125} \mathrm{I}$-AVP clearance ranged from 36.6 to 118 $\mathrm{ml} / \mathrm{min}$. These clearance calculations were based on voided urine specimens and "mean" plasma concentrations. The present values for renal clearance are in close agreement with those reported for hydrated subjects by Robertson, using a specific radioimmunoassay (8). They are considerably higher than those calculated in man from conventional bioassay data (see 1 for re- 
view). However, no controlled study of clearance with bioassay and simultaneous measurement of plasma concentrations and renal excretion in man has been reported. The state of hydration may play a role since our subjects were overhydrated and those of Lee (26) and Noble and Taylor (27) were dehydrated. Higher renal clearance has been demonstrated during hydration (8). Another possible explanation would be the excretion of $\mathrm{ADH}$ inactivated by the kidney, not measured by bioassay, but recognized by its radioactive label. Inactivation of AVP has been shown to occur in rat kidney slices (28) and homogenates (29) as well as in the perfused kidney, with excretion of inactive products in the urine $(30)$. Such biologically inactive metabolites may still react in an immunoassay, depending on the integrity of the antigenic site. Finally, the presence of inhibitors and interfering compounds in unextracted urine or plasma must always be kept in mind when evaluating bioassay data. From the present data we conclude that $\mathrm{ADH}$ is eliminated principally by glomerular filtration at physiological concentration, as previously reported in dogs (31), rats (32), and rabbits (33). Renal clearance expressed as percentage of MCR in our subjects, excluding the one with unexplained low renal clearance, averaged $27 \%$. Similar values have been reported at near physiological concentrations in dogs $(34,35)$ and in man $(36)$.

Although little is known about continuity or discontinuity of $\mathrm{ADH}$ secretion, daily production rates could be estimated from our data. Assuming a plasma AVP level of $1 \mathrm{pg} / \mathrm{ml}$ during hydration (6), daily production could be calculated to range from 0.3 to $0.5 \mu \mathrm{g}$ (or 140$240 \mathrm{mU}$ ) in our subjects under hydrated conditions.

The present study of the metabolic fate of $\mathrm{ADH}$ in man suggests certain modifications of concepts derived from animal experiments and bioassay methods of low specificity. If the behavior of exogenous ${ }^{125} \mathrm{I}-\mathrm{AVP}$ can be extrapolated to endogenous AVP, it may be concluded that circulating $\mathrm{ADH}$ is not bound to plasma proteins. ADH diffuses readily into a space approximating the extracellular fluid volume, it has a plasma half-life of about $24 \mathrm{~min}$, and its urinary clearance accounts for about one-fourth of the total metabolic clearance. Metabolic breakdown of $\mathrm{ADH}$ occurs within a few minutes, is partially intravascular, and results in metabolites which are rapidly eliminated. A half-life of 24 min appears more consistent with the duration of the antidiuretic action of $\mathrm{ADH}$ than the shorter half-lives previously reported.

\section{ACKNOWLEDGMENTS}

The authors wish to thank Dr. E. J. Rayfield for allowing them to study some of his normal control subjects, and Dr. A. Chrambach for valuable advice regarding polyacrylamide gel electrophoresis.
This work was supported by grants HD-03006 and FR31-06 from the U. S. Public Health Service, and the William F. Milton Fund of Harvard University.

\section{REFERENCES}

1. Lauson, H. D. 1967. Metabolism of antidiuretic hormones. Am. J. Med. 42 : 713-744.

2. Silver, L., I. L. Schwartz, C. T. O. Fong, A. F. Debons, and L. K. Dahl. 1961. Disappearance of plasma radioactivity after injection of $\mathrm{H}^{3}$ - or $\mathrm{I}^{1 \mathrm{~m}}$-labeled arginine vasopressin. J. Appl. Physiol. 16: 1097-1099.

3. Sjöholm, I., and G. Rydén. 1967. Half-life of oxytocin and lysine-vasopressin in blood of rat at different hormonal states. Acta Pharm. Suec. 4: 23-30.

4. Klein, L. A., and J. Roth. 1967. Antidiuretic hormone metabolism studied by radio-immunoassay. Surg. Forum. 18: 289-291.

5. Beardwell, C. G. 1971. Radioimmunoassay of arginine vasopressin in human plasma. J. Clin. Endocrinol. Metab. 33: 254-260.

6. Robertson, G. L., E. A. Mahr, S. Athar, and T. Sinha. 1973. Development and clinical application of a new method for the radioimmunoassay of arginine vasopressin in human plasma. J. Clin. Invest. 52: 2340-2352.

7. Skowsky, W. R., A. A. Rosenbloom, and D. A. Fisher. 1974. Radioimmunoassay measurement of arginine vasopressin in serum: development and application. J. Clin. Endocrinol. Metab. 38: 278-287.

8. Robertson, G. L. 1972. The physiology of vasopressin (VP) excretion in man. Clin. Res. 20: 778. (Abstr.)

9. Schally, A. V., H. S. Lipscomb, and R. Guillemin. 1959. Chromatographic separation of oxytocin and vasopressin on carboxymethylcellulose. Biochim. Biophys. Acta. 31: 252-254.

10. Hunter, W. M., and F. C. Greenwood. 1962. Preparation of iodine-131 labeled human growth hormone of high specific activity. Nature (Lond.). 194: 495-496.

11. Böhlen, P., S. Stein, W. Dairman, and S. Udenfriend. 1973. Fluorimetric assay of proteins in the nanogram range. Arch. Biochem. Biophys. 155: 213-220.

12. Cahnman, H. J. 1972. Iodoamino acids. In Methods in Investigative and Diagnostic Endocrinology. J. E. Rall and I. J. Kopin, editors. Noord-Hollandche Uitg. Mij., Amsterdam. 27-51.

13. Jovin, T. M., M. L. Dante, and A. Chrambach. 1970. Multiphasic buffer systems output, PB No. 196085 to 196091, 203016, National Technical Information Service, Soringfield, Va. 22151.

14. Chrambach, A., and D. Rodbard. 1971. Polyacrylamide gel electrophoresis. Science (Wash. D. C.). 172: 440 451.

15. Herbert, V., K-S. Lau, C. W. Gottlieb, and S. J. Bleicher. 1965. Coated charcoal immunoassay of insulin. J. Clin. Endocrinol. Metab. 25 : 1375-1384.

16. Husain, M. K., N. Fernando, M. Shapiro, A. Kagan, and S. M. Glick. 1973. Radioimmunoassay of arginine vasopressin in human plasma. J. Clin. Endocrinol. Metab. 37: 616-625.

17. Ahmed, A. B. J., B. C. George, C. Gonzales-Auvert, and J. F. Dingman. 1967. Increased plasma arginine vasopressin in clinical adrenocortical insufficiency and its inhibition by glucosteroids. J. Clin. Invest. 46: 111123.

18. Yoshida, S., K. Motohashi, H. Ibayashi, and S. Okinaka. 1963. Method for the assay of antidiuretic hormone in plasma with a note on the antidiuretic titer of human plasma. J. Lab. Clin. Med. 62 : 279-285. 
19. Cameron, D. P., H. G. Burger, K. J. Catt, and A. Doig. 1969. Metabolic clearance rate of radioiodinated human growth hormone in man. J. Clin. Invest. 48: 1600-1608.

20. Robertson, G. L., L. A. Klein, J. Roth, and P. Gorden. 1970. Immunoassay of plasma vasopressin in man. Proc. Natl. Acad. Sci. U. S. A. 66: 1298-1305.

21. Fong, C. T. O., L. Silver, D. R. Christman, and I. L. Schwartz. 1960. On the mechanism of action of the antidiuretic hormone (vasopressin). Proc. Natl. Acad. Sci. U.S. A. 46: 1273-1277.

22. Thompson, E. E., P. Freychet, and J. Roth. 1972. Monoiodooxytocin: demonstration of its biological activity and specific binding to isolated fat cells. Endocrinology. 91 : 1199-1205.

23. Miller, L., L. Fisch, and C. R. Kleeman. 1967. Relative potency of arginine-8-vasopressin and lysine-8-vasopressin in humans. J. Lab. Clin. Med. 69: 270-291.

24. Schröder, R., and D. Rott. 1959. Über die Bestimmung und das Verhalten von ADH im menschlichen Plasma. Klin. Wochenschr. 37 : 1175-1181.

25. Czaczkes, J. W., C. R. Kleeman, and M. Koenig. 1964. Physiologic studies of antidiuretic hormone by its direct measurement in human plasma. J. Clin. Invest. 43: 16251640.

26. Lee, J. 1963. The estimation of vasopressin in the blood and urine of hydrated and dehydrated subjects. $J$. Physiol. (Lond.). 167: 256-262.

27. Noble, R. L., and N. B. G. Taylor. 1953. Antidiuretic substances in human urine after haemorrhage, fainting, dehydration and acceleration. J. Physiol. (Lond.). 122: 220-237.
28. Thorn, N. A., and N. B. S. Willumsen. 1963. Inactivation of arginine- and lysine-vasopressin by slices from different zones of the rat kidney and by rat liver slices. Acta Endocrinol. 44 : 545-562.

29. Walter, R., and H. Shlank. 1975. Differences in the enzymatic inactivation of arginine vasopressin and oxytocin by rat kidney homogenate. Endocrinology. 96: 811-814.

30. Walter, R., and R. H. Bowman. 1973. Mechanism of inactivation of vasopressin and oxytocin by the isolated perfused rat kidney. Endocrinology. 92: 189-193.

31. Harvey, N., J. J. Jones, and J. Lee. 1967. The renal clearance and plasma binding of vasopressin in the dog. J. Endocrinol. 38: 163-171.

32. Ginsburg, M. 1957. The clearance of vasopressin from the splanchnic vascular area and the kidneys. J. Endocrinol. 16: 217-226.

33. Jensen, S. E., P. Frandsen, and A. T. Nielsen. 1973. Comparative experiments on the urinary excretion of exogenous oxytocin and vasopressin. Acta Endocrinol. 73: 643-650.

34. O'Connor, W. J. 1951. The rôle of the neurohypophysis of the dog in determining urinary changes, and the antidiuretic activity of urine, following the administration of sodium chloride or urea. Q. J. Exp. Physiol. Cogn. Med. Sci. 36: 21-48.

35. Thorn, N. A., and M. W. Smith. 1965. Renal excretion of synthetic arginine-vasopressin injected into dogs. Acta Endocrinol. 49 : 388-392.

36. Orr, J., and A. N. Snaith. 1959. A method for the estimation of antidiuretic hormone in urine. J. Endocrinol. 18: xvi. (Abstr.) 